\title{
KERNASPEKTE VAN DIE KENNISSOSIOLOGIE VAN KARL MANNHEIM
}

\author{
A.D. Louw \\ RGN, Privantsak $\times 417$, Preloria
}

\section{ARSTRACT}

The author deals with certain crucial aspects of the sociology of kinwledge of Karl Mannheim in view of the fact that he finds that the increase, worldwlde, of interest in ideological difficulties in South Africa can fruitfully be dealt with in terms of this form of sociology. This is iustified in part by Mannheim's viewpoint that thought is a function of human existence, and this function emanates from needs based on social factors He traces Mannheim's use of the term ideology (in Soriology), culminating with the idea that "the birth and death of ideology depends on certain social, economic and 'ecological' factors". Subsequently he deals with a whole line of aspects of the sociology of knowledge as expounded by Mannheim, culminating in the idea that shifts in views with regard to lifeview and underlying values take place when there is a rapid upward (vertical) mobility, leading to uncertainties and a lack of trust in established values.

He concludes the article by referring to the "social determination of actual thinking" and then especially the "existential determination of knowledge". The point is made that because of the correlation between life-situation and thought process there could be a deterministic interpretation of situation. This leads to a certain one-sidedness in his work which constitutes one of the main points of criticism to his work, together with his handling of the concept of knowledge and his strongly historical bias.

In 'n worreld wat toenemend gekennerk word reur botsende belinge en uiteenlopende slandpunte op bykans elke terreil van die samelewing, is die openbare andag gewonnlik hoolsaaklik gevestig of die onderhawige kwessie waromlieen die ganghare geskille gevoer word. In vele gevalle 205- 
weerspieäl die divergerende gesigspunte van onderling opponerende groepe en gemeenskappe nie die dieperliggende en onopsigtelike invloede wat matskaplike faktore dikwels in die lewensituasies van sulke groepe en gemeenskappe uitoefen nie.

Met die toename in wéreldwye belangstelling in die Suid-Afrikanse intorne belangeverskille, gepaard met 'n styging in die omvang van ideolngiese geskille, nasionaal en intermasionaal, is dit nie onvanpas om weer kennis te nerm van die bolangrikheid van die kennissosiologie vir. besinners oor die problematink van die plasslike situasie nie. Om hierdie rede is die gedagtes van die sosioloog Karl Mannheim vandag vir Suid-Afrikaners not so aktueel as in die vorlede, toe plaaslike gebeure vir die internasinnale gemennskap van minder bolang was en interne ichologiese geskille hoofsaaklik tot en bevolkingsgroep beperk was.

Ry 'n eerste kennismann van die inhoud van Mannheim se denke vind die student in die Sosiolngie dikwels moeito om die besonrlere aard van hierdie skrywer se gesigspunte te vartolk. Nie net is sy skryfstyl op verskeie plckke moeilik volgbaar nie, maar die veelal hoë vlak van abstraksie maak die volgehoue lers van veral sy hoofgeskrifte inderdaad veeleisend. Nogtans word sy werke nog sterds wyd golees. Die uitklaring van 'n aantal begrippe en kerndenkbrelde in sy beskorings van dic samelewing kan egter verhelderend werk vir veral die leser wat 'n bohoefte vnel on enigermate 'n oriëntasie in sy denke te ondergaan maar oor min agtergrond in die kennissosiologie beskik. Terselfdertyd sal 'n bondige waardebepalende bespreking ' $n$ aanduiding kan gee van die plok wat sy kennissosiologie in die breë bestek van die sosiologiese spektrum inneem.

Mannlieim se sieninge van die kennissosiologie is primer vervat in sy werke idnology nurl Utopin : An introrluction to the sorjology of knowlerlge (1936) en lissays on the Soctology of knowledge (1952). Saam vorm hierdie twre werke een van die indringandste en titvoerigste ondersoeke tot dusver na die grondslae van die kennissosiologie. Eersgenoemde werk, warvan in deel oorspronklik in Duits verskyn het, behels reeds al die kerngedagtes van Manulieim se sosiologiese perspektief. Dit was een van die eerste geskrifte warrin daar in die titel van 'n werk - in hierdie geval die deeltitel - van die woorde "sorinlogy of knowledge" gebruik gemakk is. Harris (1968:15) linem dit 'n "pionier work", Ascoli (1938:103) -201 - 
bestempel dit as "a document of great and lasting value" Birnbaum (1971:439v1.) noem dit 'n "classical reference" on Bluhm (1974:20) verwys na die outeur daarvan as "known as the father of the 'sociolngy of knowledge". Dil is dan ook hierdie werk wat as hoofverwysingsbron vir die doeleindes van ons bespreking sal dien.

Wesenlik is Mannheim se standpunt dat dic denke 'n funksie van die menslike bestaan is en dat hierdie funksie primer 'n uitvineisel is van behoeftes gebaseer op matskaplike faktore. Met hierdie siening volg Mannheim in die spore van Marx en l)urklieim, wat onk in 'n mindere of meerdere mate die invioed van matskaplike faklore op die denke angerank het. Vir Marx (1942:356) was dit mense se "social being that determines their consciousness", terwyl Durkliaim van din begrippe klas, tyd, ruimte en kousaliteit beweer dat "the things which they express are of a social nature" en "their contents are the different aspects of the social being" (1915:140).

Mannleim se kennissosiologic is wesenlik 'n uitbouing van sy teorie oor ideologie, en laasgenoemde lang ten nouste saam met die sosiale grondslag of konteks van enige groep wat deur in spesifieke perspektief. Inwens of wêreldheskouing gekenmerk word. Laasgenoemde is herleibaar na en word oorwegend beïnloed deur faktore in die sosiale omstandighede van daardie gromp on wanneer hierdie faktore verander, vind daar ook verandering plaas in die sieninge en perspektief van die onderhawige groep. Dit is dus moontlik, beweer Manmlieim (1936:73-71), 'to investigate the liypothesis that, in the past as well as in the presont, the dominant modes of thought are surplemented by new categories when the social basis of the group, of which these thought-forms are cluaracteristic, disintegrates or is transformed under the impact of social change".

Die ontleding van die situasie van in spesifieke groop ten einde 'n verband te vind tussen groepsituasie nn groepdenke beslaan, volgens Mannheim, dis kern valı in ideologiese analise. As hierdic beginsel na alle grocpe en van alle tye deurgetrek word, en elit ook op die situssie van die ontleder en sy eie omslandighede an behoeftes toegepas word, het ons met die kennissosiologie te doen. I aasgenoemde noem Manmheim sy eie "general form of the total conception of ideology". In lerinc hiervan kan die ontleder dus ook 'n ideologieanalise van sy eie standpunte 
naas dié van ander onderneem. Die algemene vorm van die totale konsepsie van ideologie hest egter altyd te doen met die tolale algemene denkstruktuur van 'n individu of groep en nie met die ideosinkratiese aspekte daarvan nie. Dit gaan hier on denke wat tiperend is van 'n besonder perspektief of lydvak wat na 'n spesifieke situasie herleibar. is Die kennissosiologie stel hierdie denkstruktuur tot probleem "as it appears in different curronts of thought and historical-social groups" (Mannheim. 1036:233). Geisoleerde uitlatings en bewerings vorm rus geen studieobjek vir die kennissosiologie nie anngesien hulle verdraairl, vervals of nie-veıtepnwonrdigend van in bepaalde gesigspunt of rlenktrant mag wans. Hulle dien egter wel as studienbjek indien hulle in bepaalde denkstruktuur wecrspicël.

Van die ideologiese dimensie in die menslike denke en die verhand daarvan met die sanelewingsopset inerk Manulinim (1936:239) die volgende op: "

the use of the terin 'ideology' in the sociology of knowledge has no moral or denunciatory intent. It points rather to a resparch interest which leads to the raising of the question when and where social structures come to express themselves in the structure of assertions and in what sense the former concretely determine the latter". Dit is dus die taak vall die kenurssosiologie on ondersoek in te stel na die matskaplike bepaaldlieid vin die denke - die wyse warop dit plaasvind, sowel as die onvang daarvan. Die definisie van die kennissosiolngie formuleer liy soos volg: " . . a discipline which explores the functional dependence of each intellectual standpoint on the differentiated social group reality standing behind it, which sets itself the task of retracing the evolutions of the various standpoints" (Mannhoin 1952:190)

Die ontwikkeling van standpunte word dour Mannheim ten nouste aan sosiale posisie gekoppel, en hieroor merk Parsons (1969: 1054) of dat "any treatment of the problems of empirical rationality and its limitations in a sociolngical context would be incomplete without Mannheim's statement of position". I a Palombara (1971:257 258) wys vooits or Maunlieion se belangrike bydran met betrekking lot sy klem op die siening dat "the bit th and death of ideoluag depenrls on certain sorial, economir. and ecological factors". 
1. Die begrip "ideologie", waatomhern die kennissosiologie verweel is, is ontwikkel teen die agtergrond van politioke worsteling. In die konteks van opponering en strycl assosieer Mannheim die begrip met heersende groepe wie se denke so belangegebonde geword het dat lulle nie meer in staat is om feite rak te sien wat vir hulle oorheersingsgevoel olldermynend is nie. Die bngrip impliseer vourls dat groepdonke in sekere situasies die werklike nnstandighede van die sanclewing vir sigself sowel as vir andere verduister. Hierteenoor staan utopiese denke, d.i. revolusionére idcologiëe, wat verteenwoordigend is van die gesigspunt van sokere onderdrukte groepe. Laasgenoemde is so intens gemoeid met die vernietiging of omvorming van ' $n$ gegewe toestand in of van din samelewing dat hulle onwetend slegs die negatiewe aspekte van die sitursie onderken. "Iheir thought is never a diagnosis of the situation: it can be used only as a direction of action ... (it) hides cerlain aspects of reality. It turns its back on everything which woulet shake its betief or paralyse its desire to change things" (Mannhrim 1936:36). Lit was hier, volgens Mannheim, op die tonnel van politieke konflik, dat die besef gekristalliseer het van dis rol van onbewuste kollektiewe motiveringe onderliggend aan uiterulopende denkrigtings binne sowel as buite die veld van politieke handeling.

2. Waar die begrin "idenlogie" in die politieke kacter dikwels tenll opponente as " verwyt of beskuldiging vir onpraktirse denke aangewend is, verkry dil in die kennissosiologie akademiese status. "What was once the intellectual armamnnt of a party is transformed in to a method of research in social and intellectual history generally" (Mannheim 1936:G9). Dil is dus die taak van die sosissogiese geskiedenis van die denke om "n onparlydige, of te wol nie waardebmalnnde, ontleding te voltrek van alle montlike faktore wat in enige gangluare of gewese sosiale situasie 'n invlond on denke het of kon gehad het. So in sosiologiegeoriěnleerde geskiedenis van denkbeelde sal, volgens Manmheim (ibid), die modnrne mens voorsien van in hersienc visie on die historiese proses in sy geheel. 
3. As nie wardebepalende gesigpunt vir sosiologiese analise betrek die kennissosiologie geen regstreekse epistemologiese of ontologiese implikasies wat dit vir empiriese aanwending onaanvaarbaar maak nip. Dit is nie ' $n$ warlueidsteorie nie. 'n Ideologiese analise wil nie op in relativisme afstuur nie maar wel op in metodologiese grondslag instrumenteel belekenisvol wees. Toepaslik is lieer Apter (1961:39) se npmerking oor sosiale wetenskap en idrologie: "Social science has becnme the ullimate ideology and scienre the ultimatr talisman against cynicism. It defines its own purposes through the logic of enquiry".

4. Die begrip "denke" is onlosmaaklik verbonde aan ulie begrip "klas". Konsepsics (rlanke) liang saam met sosiaal-historiese kontekste - veral met klassestruktuur en klasseverhoudinge en "the structure of sorinty and its corrosponding infellectual forms vary with the reIations between social classes" (Mannlieim 1936:60) Mannlipim, soos Marx, verteenwordig dus in strukturalistiese benadering.

5. Wonneer Mannheim gebruik maak van uitsprake soos "structural differences in minds". "forms of knowledge", "categories (of thought) other than our own" en "fundamentally divergent thought systrins". gaan dit hie om verskille in die logisiteit en eie aard van die denke self nic maar om verstilln lussen waardeoriëntasies wat situasiegebonde is. Na gelang hohooftes en waardes binno sposifieke knntrkste variecr, verskil denkratrone in en oor daardie kontekste. Dit gaall in werklikheid on ideologiese of te wrol perspoktiwiese verskilte wat teil nousle saanliang met maatskaplike faktore in die situasie van die groep of kollekliwiteit self. "Knowlerlge is fron the very beginning a co-uperative process of group life in which overyore unfolds his knowledge within the franework of a conmon fate, a common activity, and the overcoming of common difficullies... the subordinate groups and state in a functionally differentialed socirty have a different experiential approach to the common contents of the objects of their world" (Mannheirn, 1936:26).

6. Vir begrip "kennis" in die tetil kentenissosiologie dui nie net bloot op reitelikheid nie. Inloude is vir Mannheim slogs betekenisvol in die sin dat hulle draers van normatiewe en wardeorin̈ntasirs is. "The full emergence of the sociological point of view regarding $-210-$ 
knowledge carries witl it the gradual uncovering of the irrational foundation of national knowledge" (Mannlucim, 1936:28). Die begrip "kennis", net sons die begrip 'Wissen' in die oorsrronklike term Wisscnssoziologie, wys in die kennissosiologie heen op enigiets warvan mense hewus is of warvan hulle crvaring het afyesien van die aard daarvan.

7. As aanvaar word dat warrdeoriëntasies en waardesisteme onvermydelik ook betekenissisteme is, word dit duidelik waarom Mannheim alle denke as sosiaal-histories bepaald beskoul. Van betekenisse oP groepvlak merk hy op dat liulle 'gebeure' vir die groep 'sosialiseer'. Voorts: "We belning to a group ... primarily because we see the world and certain things in the world the way it does (i.e. in terms of the meanings of the group in question). In every concept, in evary concrete meaning, there is contained a crystallization of the exprei ences of a certain group" (Mannheim, 1936:19). Hierrlie insig is vir Mannlieim (1936:61) van kardinale belang vir begrip van historiese tydvakke: "Fvery fact and event in all hislorical proiod is only explicable in terms of meaning, and meaning in its turn always refers to another meaning. Thus the conception of the unity and interdependence of meaning in a period always underlies the interpietation of that period interdependent system of meanings varies both in all its parts and its lotality from one historical period to allother". Die begrip 'betekenis' verkry so 'n wesenlike plek in ideologiese ontledings binne die kennissosiologin angesien, in groeps- en kollektiwileitsverband, slegs dit betekenisvol kan wees waaraan betekenis torgnskryr word. Hierdie npvatting is war.skynlik die kern van Mannlieim se beskouings betrefferde die verhouding tussen groendenke en groepsituasie.

8. Dat waredes, norme en donlstollings inhoudelik as objektiewe sosialn entiteile beskou moet word, word deur Manmheim (1936:73) summier afgewys: "The view which holds that all cullural life is an orientation towards objective values is just one more illustration of a typically modern rationalistic disregard for the basic irrational merhanisms which govern man's relation to his wrild". Dieselfde gelel vir norme: "Yliere is ... no norm which can lay claim to formal validity and which 
can be abstracted as a constant universal formal element from its historically changing content" (ihjd)

Uit bostaande is dit duidelik dat Manmheim hom van n rasionalistiese benadering in die wetenskap distansieer. Sy voorkeur is vir dic irrasioncle onderbou in menslike gedrag, en sy studieotiok is altyd die individuele groep of kollektiwiteit in situasieverband.

Mannhoim (1936:75) wys die montliklıeid af van blywende watheid in, of sekerheid van, ons kennis van die wereld. Oit is eerder die mens se onsekerheid wat hom in staat stel om veel nader aan die realiteit te beweeg. Sy opvatting van die begrip 'feit', as verbandhourlend net die begrip 'waarheid', heredeneer hy soos volg: "... the question of the nature of facts is in itself a considerable problem. They exist for the mind always in an intallectual and social context. That they can be understond and formulated implies already the existence of a conceptual apparatus. And if this conceptual apparatus is the saine for all the members of the group, the presuppositions (i.e. the possible social and intellectual values), which undriflie the individual concepts, never become perceptible. The sommambulistic certainty that has existed with reference to the problem of truth during stable periods of history lhus becomes intelligitsle" (Mannhrim, 1930:91).

9. Die moontlike aanklag leen die kenuissosiologie as sou dit relativisties wces, wojed drur Manutipion op grond van sy begrip 'relasionisme' tenngestain. Onder laasgenonmde verstann hy " raamwerk van onderling samohangenrle betrkenisse wat in 'n bepaalde maatskaplike situasie gold. "Such a system of meanings is possible and valid only in a givan tyre of historical existence to which, for a time, it fur. nislies arpropriate expression" (Mannheim, 1936:76). Maar rlit beteken nie dat 'n stel betokenisse of ' $n$ realiteitsvisic bloot skyn is omdat dit situasingeisonde is nie. Dit beteken wel dat daar onderliggend aan alle kennis en gesigspunte ene of ander faktor of stel faktore annwesig is wat $n$ ideologiese rol speel in die situasie van diegnne wat dit tot stand bring 
10. Die verskillende manifestasies van kennis en gesigspunte is tekenend van die diversiteit van die inaatskaplike realiteit. Die nie-wardebepalende konsepsie van ideologie wil hiermen rokening hou en daardeur onbevooroordeelde erkenning verleen ann dip eiewaarde van elke vorm van groepsuitdrukking. "We have ... as the thmme of this non-evaluative study of ideology the relationship of all partial knowledge and its component elements to the larger body of maning. and ultimately to the structure of historical reality" (Mannheim, 1936:77). Die verskeirdenheid gesigspunte en vorme (manifrstasies) van kennis het dus onderling 'n komplcmentère en/of supplementére funksie in die lang evolusionêre en historiese proses van wording en verandering. Die saambestaan van verskillencle perspektiewe impliseer egter nie neutraliteit en onderlinge verdraagsaamheid nie; intecndeel, "narrowness and the limitations which restricl one point of view tend to be corrected by clashing with the opposite points of view" (Mannheim, 1936:72).

Hierdie siening van Mannheim, naanlik dat ontwikkeling via onderlinge stryd geskied, plaas hoon onmiddellik in die tradisie van die konfliksosiologie.

11. Volgens Mannlieim vind verskuiwings in opvallinge oor lewensbeskouing en grondliggende waardes plaas wanneer sur.lle vertikale mobiliteit geskied. Ilierdie verskuiwings bring onsekerheid mee wat tot ' $n$ verlies aan vertroue in gevestigde waardes lei. Mannlucim werk egter nie 'n teorie vir sosiale verandering uit om vertikale mobiliteit te verklaar nie.

\footnotetext{
Oor die aard van die kennissosiologie stel Mannheim dit dat hierdie dissipline 'n tweeledige karakter het. Enorsyds is dit ' $n$ teorie en andersyds in histories-sosiologiese navorsingsmetode. Omdat die kentuissosiologie by uitstek bekend is vir die teoretiese trefkrag daarvan, sal daar in die volgende paragrawe slegs aan hierdie kant van die disipline aandag bestee word.

Dit gaall in die kennissosiologie om empiriese ondersonke na die mantskaplike lmpanldlield van die 'denke' ('thought') en 213-
} 
'Hennis'('knowledge'). Mannheim noern dit die "social determination of actual thinking" en, veral, die "existential determination of knowledge". llierdie bueë formulering perk hy enigermate in met die volgende kwalifikasies: die invloed van situasinnele faktore op die denke kan as in feit beskou word indien angetonn kan word, ten eerste, dat in sekere verlakkinge van die denke die mens se proses van kennisverkryging hislories hie volgens suiwer Ingiese monntlikliede of volgens immanonte wette ontwikkel het nie maar in vele kritieso opsigte deur nie-kognitiewe of to wel eksistensiöle faktore beinvlond is; tell twerde dat die invloed van hierdie faklore die konkrete inhoudelikheid van kennis in so in mate binnedring dat dit in beslissonde uitwerking het op die aard en omvang van kollektiwileite of groepe se ervaring en waarnoning van hulle siluasie. Dil gaan naamlik om invloede op die 'perspektief' van die groep. Onder hierdin begrip verstaan Manmheim (1936:239) die volgende: "It points ... to a research interest which leads to the raising of the question when and where social structures come to express thomselves in the structure of assertions, and in what sense the former concretely determine the latter".

Oor die begrip 'determineer', sons deur Manuheirn aangewend, dien enkele opmerkings gemaak te word. In sy bespreking van die verband tussen groepctenke en eksistensiäle (situasionele, matskaplike) faktore gebruik hy verskillende terme om die aard van die relasie aan te tonn. Voorbeclde hiervan is "comected with", "intimate interaction", "conditioned by", "correlatives of", "functional dependence", "express", "characteristic of" en "determinc". Tie rolasie is dus nie uitsluitlik gestrenge of absolute deteıminerende oorsaaklikheid nie. In $n$ voelnoot in die laaste hoofstuk van Ideology and Itopta gee Mannheim (1936:239) n aanduiding van wat hy onder determinering verstaan: " . . we leave the meaning of 'de. termination' open, and only empirical investigation will show us how strict is the correlation between life situation and thought process, or what scope exists for variation in the correlation".

In die lig van bognenoende blyk elit dus dat daar regverdiging is vir 'n breë interpretasie van die laak van die kennissosiologie, en verskeie skrywers het reods in 'n mindere of meerdere male hieraan aandag gegee (vgl. Botomore, 1956; Stark, 1958, hist. 3; Recker en Dahlko, 1942:310-11; Frankel, 1956; en Arian, 1967, se studie or die invloed 
van denkbeelde op warmeming en gedrag). Alhoewel Mannheim (1952:275) erken dat wederkerige beinvloeding tussen denke en matskaplike situatisties moontlik is, liet sy benadering wesenlik 'n determunistiese inslag gehad. Wanneer hy oor die invloed van die ekonomiese sisteem op mense se denke skryf, erken hy dat hy die omgekeerde potensiaal van die verhouding nalaat ter wille van 'n spesifieke doelstelling, naamlik: " .. we wished for once to work out all implications of one aspect of the connection betwenn the two" (Manmliein, 1952:27). Hierdie beklemtoning van enn pool van die relasics wat liy onder ö̈ neem, naanlik dis diepliggende en indringende funksie van nie kognitiewe faktore, word deurgaans deuf hom gehandhaaf. So stel liy ook die wiskunde en tegniese varudighede - die enigste manifestasies van denke wat hy as 'neutraal' of te wel nic-ideologies klassifiseer - onder menslike beloeftes aan dic oorkouning van probleme in die lewenssituasie. Tegniek (en tegnologie) is dus vir hom ontwikkelings wat in diens van ander breër lewensbelange staan.

Dic belangrikste kritiek teen Mannheim vloei juis uit hierdie eensydigheid van sy bespreking voort. Verskeie sosioloë liet sy kennissosiologie as relatiwisties beoordeel - "n aanklag wat Mannheim voorsien luet en wat hy met sy lering oor relasionisme probeer teenstaan het. Sy relasionisme gaan egter gobuk onder 'n miskenning van die eie kriloria van die denke en 'n gebrek aan 'n onderskeiding tussen verificerbare konnis enersyds en blote menings, beskoningo, opvattings en aanvaardinge op grond van oorlewering andersyds. Die denke word te eensydiglik geskilder as die produk vall 'n sosiaal historiese situasie en dit lei daartoe dat die ontstaan van wetenskaplika kennis as 'n matskaplikn instelling met '" eie geskiedenis negeer word. Om hierdic rede ontsnap Mannheim nie die aanklag van determinisme nie en is sy kennissosiologie meer toepaslik op nie-tegnologiese samelewings en gemeenskappe, en op maatskaplike strukture warin mag (en politieke handeling) as instelling 'n dominante posisie inneem teenoor alle ander instellings.

Hierdie kritiek geld vir Mannheim se kennissosiologie maar nie vir sy icleologiekonsopsie nie omdat lasgenoonde wesfonlik 'n metodologiese legniek behels, nic ewaluatiof is nie en spesifiek gemocid is met die blootlegging en uitligling van die relatiewe en veranderlike nemente in situasiegebonde idees en betekenissisteme. Die ideologiese analise leen -215 - 
sig besonder effektief vir begrip van situasies van konflik of potensiële konflik afgesien van die vlak waarop dit geskied.

Die liedendaagse wetenskapsosiologie kan regstreeks na Mannlieim se kennissosiologie herlei word in die $\sin$ dat dit 'n uitvloeisel van die kritiese evaluering van sy konsepsie van kennis is. 'n Tweede uituloeisel hiervan, maar veel resenter, is die ontwikkeling vall 'n 'Sociology of Belief (Dixon, 1980).

Die verbetering van lewerskwaliteit vir die inheemse volke en Nic-blanke bevolkingsgroepe in die RSA skep binne die geledere van hierdie kollektiwitnite en groeperinge strewes wat opsigtelik weerspieäl word in die uitsprake van kerklike, politieke en kultuurleiers. In die rasionele beargumentering van wenslik en onwenslik binne en tussen die onderskeie groeperinge, insluitende die heersende Blanke segment, word op ininder opsigtelike wyse van die diepste groepswaardes in die spel gebring waardes wat in verband gebring kan word met groepservaring. situasiegabondenheid en snsiale posisie d.i. matskaplike faktore wat " belangrike rol speel in die lewenspatroon en lewensuitkyk vall groeperinge en gemeenskappe wat sosiaal verwyderd staan van mekaar. Mannhein se verdienste is dat liy die rol van hierdie nis-opsigtelike faktore pertinent onder die andag gebring het.

RRONNI:I,YS

APTER, D.E. 1964. ad. Ideology and discontent I ondon: The Free Press.

ARIAN, A. 1967. The role of ideology in determining behaviour. The Soriological Review, 15 (1):47-57.

ASCOLI, Max. 1938. On Mannheim's 'Ideology and Utopia'. Social Rescarch, February, 101-106.

BECKFR, H., DAIII KE C. 1942. Max Sclieler's sociology of knowledge. l'hilosopliy and plicunmenological resenrch, 2 : 310-322. March. 
DIRNBAUM, N. 1971. Toward a critical sociology. New York : Oxford University Press.

BI.EIIM, W 1. 1974. Ideologies and altiludes : modern political culture. Englewood Cliffs, N.I. : Prentice-llall.

BOTTOMORE. T.B. 1956. Some reflections on the sociolugy of knnw ledge. The Brilish Journal of Soctology. $7: 52 \cdot 58$.

DIXON, K. 1980). The Sociology of belicf. London :Roullndge and Kegan Pais.

DURKHEIM, Emile. 1915. The elementary forms of the religinus life. Translated by J.W. Swain Lonclon : George Allen and Unwin.

FRANKFL, C. 1956. The case for mudern man. New York: Ilarper.

IIARRIS, N. 1968. Beltefs in society. Middlesex: Penguin Books.

LA PALOMBARA, J. 1971. A dissenting view. (In Rejai, M. Decline of ideology. Chicago: Aldine-Atherton, $\mathrm{np} .257-258$. )

MANNHEIM, Karl. 1936 Ideology and Utopia. I.ondon : Roulledge and Kegan Paul.

MANNIIEIM, karl. 1952. Essays on the sociology of knowledgr. New York : Oxford University Press.

MARX, Karl. 1912. A contributinn to the critique of molitical economy. (lin Dutl, C.P. Karl Harx, seleceted wolks. Vol 1. London : Lawrence and Wishart, P. 356.)

PARSONS, Talcott. 1969. Valun and belief patterns. Pait four, Sec. B. (In Parsons, Talcott it al. Theories of Sorinly, Vol.ll. New York the Free Press, p. I0lj4.)

STARK, W. 1958. The sociology of knowledge. London: Routledeje and Kegan Paul. 